EXTENDED REPORT

\title{
Anti-telomere antibodies in systemic lupus erythematosus (SLE): a comparison with five antinuclear antibody assays in 430 patients with SLE and other rheumatic diseases
}

\author{
E M Salonen, A Miettinen, T K Walle, S Koskenmies, J Kere, H Julkunen
}

Ann Rheum Dis 2004;63:1250-1254. doi: 10.1136/ard.2003.011890

See end of article for authors' affiliations

Correspondence to: Dr H Julkunen, Peijas Hospital, 01400 Vantaa, Finland; heikki.julkunen@ hus.fi

Accepted

19 December 2003
Objective: To investigate the prevalence and diagnostic significance of antibodies against telomeric DNA in systemic lupus erythematosus (SLE) and other autoimmune rheumatic diseases, and to make comparisons with five conventional anti-DNA or anti-nuclear antibody (ANA) assays.

Methods: Antibodies to telomeres, which are highly repetitive sequences of DNA (TTAGGG/CCCTAA) at the end of eukaryotic chromosomes, were measured by an enzyme linked immunosorbent assay (ELISA) in 305 patients with SLE and 125 patients with other autoimmune rheumatic diseases (78 rheumatoid arthritis, 32 primary Sjögren's syndrome, eight mixed connective tissue disease, seven miscellaneous rheumatic diseases). Other assays used were two commercial ELISA assays for anti-dsDNA using calf thymus as antigen, Crithidia luciliae immunofluorescence, and radioimmunoassay (RIA) for anti-dsDNA and immunofluorescence using Hep-2 cells for ANA.

Results: The prevalence of anti-telomere in SLE was 60\%, v 5\% in rheumatoid arthritis and $18 \%$ in other autoimmune rheumatic diseases. Specificity of anti-telomere for SLE was 91\%; positive and negative predictive values were $95 \%$ and $46 \%$, respectively. For anti-dsDNA by two ELISA assays using calf thymus as antigen, sensitivities were $69 \%$ and $29 \%$ and specificities $66 \%$ and $96 \%$, respectively. Other antidsDNA assays had low sensitivities (RIA 43\%, Crithidia immunofluorescence 13\%). The association of antitelomere with a history of nephritis in patients with SLE was stronger $(p=0.005)$ than by any other assay $(p=0.006-0.999)$. The correlations between the different assays were good $(p<0.001$ for all comparisons).

Conclusions: The new ELISA for anti-telomere antibodies using standardised human dsDNA as antigen is a sensitive and highly specific test for SLE.
$\mathrm{D}$ ifferentiating systemic lupus erythematosus (SLE) from other autoimmune rheumatic diseases and undifferentiated connective tissue diseases may be difficult. ${ }^{1}$ In a large retrospective European multicentre study including 1000 patients with SLE, the first symptoms preceded the clinical diagnosis by two years. ${ }^{2}$ This delay is mainly caused by the highly variable clinical picture of SLE, but it may also reflect the lack of a sensitive and specific laboratory test to diagnose the disease. Diagnosing SLE early and more accurately is important for patient education and for the institution of appropriate treatment to reduce morbidity.

The key diagnostic test for SLE is anti-double-stranded DNA (anti-dsDNA), which is conventionally determined by Farr assays, enzyme linked immunosorbent assays (ELISA), or indirect immunofluorescence using calf thymus or Crithidia luciliae as target antigens. ${ }^{3}$ Farr assays and immunofluorescence are reasonably specific but not very sensitive for SLE. ELISA assays are more sensitive in detecting low affinity antidsDNA, but they can easily give false positive results with other autoimmune rheumatic diseases and in concomitant infections. ${ }^{4}{ }^{5}$

Telomeres are highly repetitive sequences of DNA (TTAGGG/CCCTAA) at the end of eukaryotic chromosomes. It is possible that human antibodies against DNA could be more specific towards this particular and common repeat than towards conventionally used DNA antigens of nonhuman origin in commercially available assays. A previous study $^{6}$ showed that, of 52 patients with SLE, 96\% had IgG class, 56\% IgM class, and 85\% IgA class anti-telomere antibodies by ELISA. In another study, anti-telomere antibodies were documented in $65 \%$ of SLE patients and in $75 \%$ of patients with active disease. ${ }^{7}$ In other autoimmune rheumatic diseases (primary Sjögren's syndrome and scleroderma) and in controls, the frequencies of these antibodies were about $7 \%$. These results suggest that the anti-telomere antibody assay may be a very sensitive and specific test for SLE, and further, that it may well correlate with the clinical activity of the disease. Previous studies on anti-telomere antibodies have been quite preliminary and done in small numbers of patients, ${ }^{67}$ and the comparisons with other relevant tests have been limited. ${ }^{8}$

In this study, we employed a novel ELISA assay using human telomere dsDNA as antigen to test for anti-DNA antibodies. The results were compared with those obtained with two commercially available ELISA assays using calf thymus DNA as antigen, with a Farr assay using bacterial DNA as antigen, with a Crithidia luciliae immunofluorescence assay using kinetoplast DNA as antigen, and with an antinuclear antibody assay using human Hep-2 cells as antigen.

\section{METHODS}

\section{Patients and controls}

The study included 305 patients with SLE as classified according to the ACR criteria. ${ }^{9}$ These patients attended the outpatient departments of the University Central Hospitals of Helsinki and Kuopio and 21 other major hospitals in Finland,

Abbreviations: ACR, American College of Rheumatology; ANA, antinuclear antibody; anti-dsDNA, anti-double-stranded DNA; MCTD, mixed connective tissue disease; SLE, systemic lupus erythematosus 
Table 1 Antibody positivity among study patients

\begin{tabular}{|c|c|c|c|c|c|c|}
\hline Diagnosis & $\begin{array}{l}\text { Anti-telomere } \\
\text { (ELISA) }\end{array}$ & $\begin{array}{l}\text { Anti-dsDNA } \\
\text { (ELISA, Shield) }\end{array}$ & $\begin{array}{l}\text { Anti-dsNA } \\
\text { (ELISA, Inova) }\end{array}$ & Crithidia luciliae (IF) & Farr assay (RIA) & ANA (IF) \\
\hline SLE & $164 / 275(60 \%)$ & $142 / 205(69 \%)$ & $82 / 279(29 \%)$ & $38 / 298$ (13\%) & $126 / 291(43 \%)$ & $227 / 298(76 \%)$ \\
\hline RA & $4 / 76(5 \%)$ & $17 / 78(22 \%)$ & $4 / 78(5 \%)$ & $1 / 77(1 \%)$ & ND & $28 / 78(36 \%)$ \\
\hline Primary SS & $4 / 13(30 \%)$ & $20 / 32(63 \%)$ & $1 / 32(3 \%)$ & $0 / 32(0 \%)$ & ND & $27 / 32$ (84\%) \\
\hline MCTD & $1 / 8(13 \%)$ & $4 / 8(50 \%)$ & $0 / 8(0 \%)$ & $0 / 8(0 \%)$ & ND & $8 / 8(100 \%)$ \\
\hline Scleroderma & $0 / 4(0 \%)$ & $0 / 4(0 \%)$ & $0 / 4(0 \%)$ & $0 / 4(0 \%)$ & ND & $3 / 4(75 \%)$ \\
\hline Others* & $0 / 3(0 \%)$ & $0 / 3(0 \%)$ & $0 / 3(0 \%)$ & $0 / 3(0 \%)$ & ND & $3 / 3(100 \%)$ \\
\hline
\end{tabular}

*One case of polymyositis, one of primary biliary cirrhosis, and one of fibrosing alveolitis, the two last both with secondary Sjögren's syndrome.

ANA, antinuclear antibodies; ELISA, enzyme linked immunosorbent assay; IF, immunofluorescence; MCTD, mixed connective tissue disease; ND, not done; RA, rheumatoid arthritis; RIA, radioimmunoassay; SLE, systemic lupus erythematosus; SS, Sjögren's syndrome.

and were included in a nationwide project, the aim of which was to identify all multiplex SLE families in Finland. The recruitment process, data collection, and clinical manifestations of the patients have been described previously. ${ }^{10}$ The mean (SD) age of the 305 SLE patients was 46.2 (13.5) years, range 19 to 84 , and the mean number of SLE criteria fulfilled was 5.5 (1.4), range 4 to 10 . The majority of the patients were female $(95 \%)$.

Patients, with autoimmune rheumatic diseases other than SLE attended the outpatient departments of the Helsinki University Central Hospital and included 78 patients with rheumatoid arthritis, ${ }^{11} 32$ with primary Sjögren's syndrome, ${ }^{12}$ eight with mixed connective tissue disease (MCTD), ${ }^{13}$ four with scleroderma, ${ }^{14}$ one with polymyositis, ${ }^{15}$ and one each with primary biliary cirrhosis and fibrosing alveolitis, both of these having secondary Sjögren's syndrome. The mean age of these 125 control patients was 49.0 (12.4) years, range 18 to 76 years, and two of them were male $(2 \%)$.

Healthy controls consisted of 50 female and 35 male blood donors, 80 persons from the staff of the Helsinki University Central Hospital, and 150 persons from the staff of the Biohit laboratory. The sera from 430 patients and from 314 healthy controls were stored at $-20^{\circ} \mathrm{C}$ until tested. Not all antibody determinations were done in all patients. Missing data reflected small amounts of sera in unselected patients.

\section{Laboratory methods}

\section{Anti-telomere antibody assay}

Anti-telomere IgG antibodies were determined using a specific ELISA test (anti-dsDNA test kit, catalogue No AI 003 010, Biohit plc, Helsinki, Finland). In the test the antigen, a 60 base pair long ( 10 repeats of human telomere sequence) dsDNA, biotinylated at the $5^{\prime}$-end of one strand, is attached to streptavidin coated microplate wells. Duplicate serum samples were tested at 1:100 dilution according to the manufacturer's instructions. Between the reaction steps the plates were washed using a BW50 microplate strip washer (catalogue No 740 050, Biohit plc). The absorbances were measured with a BP800 microplate reader (catalogue No 740 030, Biohit plc). The absorbance values obtained were converted to IU/ml according to the formula included in the test kit:

$$
\begin{gathered}
\mathrm{xA}(\text { patient sample })-\mathrm{xA}(\text { blank }) \\
\frac{\times \text { standard }(\mathrm{IU} / \mathrm{ml})}{\mathrm{xA}(\text { standard })-\mathrm{xA}(\text { blank })}
\end{gathered}
$$

The upper reference value, $64 \mathrm{IU}$, for the test was set at the 98th centile for 150 healthy persons from the staff of the Biohit laboratory. This value corresponded to the 0.445 absorbance units (AU). Two samples of the 150 controls were above this value (0.514 and $0.960 \mathrm{AU}$, corresponding to 78 and 152 IU, respectively).

\section{Other antibody assays}

Anti-dsDNA antibodies to calf thymus dsDNA by ELISA were determined by two assays according to the manufacturers' instructions (Diastat ${ }^{\mathrm{TM}}$ anti-dsDNA, Shield Diagnostics, Dundee, UK, and Quanta Lite ${ }^{\mathrm{TM}}$ dsDNA, Inova Diagnostics Inc, San Diego, California, USA). The upper reference value for the former test was set at the 98th centile for 165 healthy controls ( 85 blood donors and 80 persons from the staff of the Helsinki University Hospital) and corresponded to 0.201 OD (optical density) units. Two samples of 165 were above this value ( 0.209 and 0.235 OD units, respectively). The upper reference value for the latter test was set at the 98th centile for 165 healthy controls and corresponded to $0.526 \mathrm{AU}$. Three samples of 165 were above this value $(0.538,0.558$, and 0.631 AU, respectively).

Iodinated bacterial DNA was used as antigen in the Farr assay (Anti-dsDNA test, Medix Biochemica, Kauniainen, Finland). Values of at least $7 \mathrm{mg} / \mathrm{l}$ were considered positive.

Anti-dsDNA antibodies and ANA by the indirect immunofluorescence technique were detected using Crithidia luciliae cells (NOVA Lite ${ }^{\mathrm{TM}}$ dsDNA, Inova Diagnostics) and Hep-2 cells (Nova Lite ${ }^{\mathrm{TM}}$ ANA, Inova Diagnostics) as substrates, respectively. A titre of at least 320 in the ANA assay and at least 10 in the Crithidia assay were considered positive,

Table 2 Spearman correlation coefficients of the tests among study patients

\begin{tabular}{lllllll}
\hline Antibody assay & $\begin{array}{l}\text { Anti- } \\
\text { telomere }\end{array}$ & $\begin{array}{l}\text { Anti-dsDNA } \\
\text { (Shield) }\end{array}$ & $\begin{array}{l}\text { Anti-dsDNA } \\
\text { (Inova) }\end{array}$ & RIA & $\begin{array}{l}\text { Crithidia } \\
\text { luciliae }\end{array}$ & ANA \\
\hline Anti-telomere & 1.000 & 0.720 & 0.650 & 0.604 & 0.273 & 0.360 \\
Anti-dsDNA (Shield) & & 1.000 & 0.711 & 0.492 & 0.343 & 0.429 \\
Anti-dsDNA (Inova) & & & 1.000 & 0.568 & 0.284 & 0.373 \\
RIA & & & 1.000 & 0.401 & 0.395 \\
Crithidia luciliae & & & & & 1.000 & 0.213 \\
ANA & & & & & & 1.000 \\
\hline
\end{tabular}

All values were significant at the 0.01 level.

ANA, antinuclear antibodies; anti-dsDNA, anti-double-stranded DNA; RIA, radioimmunoassay. 
Table 3 Autoantibodies in systemic lupus erythematosus and other autoimmune rheumatic diseases

\begin{tabular}{lllllll}
\hline Autoantibody (method) & Positive & SLE & Sensitivity & Specificity & PPV & NPV \\
\hline Anti-telomere & $176 / 379(46 \%)$ & $164 / 275$ & $60 \%$ & $91 \%$ & $95 \%$ & $46 \%$ \\
Anti-dsDNA (Shield) & $185 / 330(56 \%)$ & $142 / 205$ & $69 \%$ & $66 \%$ & $77 \%$ & $57 \%$ \\
Anti-dsDNA (Inova) & $87 / 404(22 \%)$ & $82 / 279$ & $29 \%$ & $96 \%$ & $94 \%$ & $38 \%$ \\
Chrithidia luciliae (IF) & $39 / 422(9 \%)$ & $38 / 298$ & $13 \%$ & $99 \%$ & $97 \%$ & $32 \%$ \\
ANA (IF) & $296 / 423(70 \%)$ & $227 / 298$ & $76 \%$ & $45 \%$ & $77 \%$ & $44 \%$ \\
Best combinations of two assays & & & & & & \\
Anti-telomere+anti-dsDNA (Shield) & $174 / 287(61 \%)$ & $140 / 183$ & $77 \%$ & $67 \%$ & $80 \%$ & $62 \%$ \\
Anti-telomere+ANA & $290 / 377(77 \%)$ & $235 / 273$ & $86 \%$ & $47 \%$ & $81 \%$ & $56 \%$ \\
Anti-dsDNA (Shield)+ANA & $259 / 331(78 \%)$ & $181 / 206$ & $88 \%$ & $38 \%$ & $70 \%$ & $65 \%$ \\
\hline
\end{tabular}

ANA, antinuclear antibodies; anti-dsDNA, anti-double-stranded DNA; IF, immunofluorescence; NPV, negative predictive value; PPV, positive predictive value; SLE, systemic lupus erythematosus.

respectively. At these titres fewer than $4 \%$ and $1 \%$ of blood donors are positive (Miettinen A, unpublished results).

\section{Statistical methods}

The sensitivities, specificities, and positive and negative predictive values (PPV and NPV, respectively) were calculated as indicated in table 3. Spearman's rank correlation was applied in studying correlations between the different assays. The Mann-Whitney U test was used to compare the levels of the antibodies in patients with or without nephritis. All $\mathrm{p}$ values were two tailed, and differences at 0.05 were considered significant.

\section{RESULTS}

\section{Prevalence of the antibodies}

If the cut off was set at the $98 \%$ centile, anti-telomere antibodies were found in $60 \%$ of patients with SLE (table 1). In patients with rheumatoid arthritis and primary Sjögren's syndrome, the prevalences were $5 \%$ and $30 \%$, respectively. In other autoimmune rheumatic diseases, anti-telomere antibodies were rare $(7 \%, 1 / 15)$.

By the two other ELISA assays, $69 \%$ or $29 \%$ of the patients had anti-dsDNA antibodies (table 1). Anti-dsDNA by RIA and immunofluorescence were present in $43 \%$ and $13 \%$ of patients with SLE, respectively. ANA by immunofluorescence using Hep-2 cells as antigen was present in $76 \%$ of SLE patients.

\section{Correlations between different assays}

Correlation coefficients between the different assays are summarised in table 2 . In general, anti-telomere antibodies correlated well with the ELISA assays $(r=0.650$ to 0.720$)$ and less well with other tests $(r=0.273$ to 0.479$)$. ANA and Crithidia immunofluorescence had the lowest correlations with other tests. All values were, however, significant at the 0.01 level.

\begin{tabular}{lc}
$\begin{array}{l}\text { Table } 4 \text { Associations of the antibody assays } \\
\text { (titres) with a history of lupus nephritis }\end{array}$ \\
\hline Antibody assay & p Value \\
\hline Anti-telomere & 0.005 \\
Anti-dsDNA (Shield) & 0.029 \\
Anti-dsDNA (lnova) & 0.024 \\
RIA & 0.006 \\
Chrithidia luciliae & 0.049 \\
ANA & 0.999 \\
\hline
\end{tabular}

ANA, antinuclear antibodies; anti-dsDNA, anti-doublestranded DNA; RIA, radioimmunoassay.

\section{Association of the tests with SLE}

Table 3 shows that the anti-telomere antibody assay was a sensitive $(60 \%)$ and specific $(91 \%)$ test for SLE, with a high positive predictive value (95\%). The most sensitive assays were anti-dsDNA by ELISA (Shield) (69\%) and ANA by immunofluorescence (76\%), but their specificities were lower (66\% and 45\%, respectively). Anti-dsDNA (Inova) and Crithidia immunofluorescence had poor sensitivities, but their specificities were high.

Table 3 shows the best combinations of two assays in the differential diagnosis of SLE. The highest sensitivities were reached by combining ANA with anti-telomere $(86 \%)$ or antidsDNA by ELISA (Shield) (88\%) but their specificities were poor ( $47 \%$ and $38 \%$, respectively). The combination of antitelomere and anti-dsDNA ( Shield) had high sensitivity (77\%) and an acceptable specificity (67\%).

\section{Association of the tests with nephritis}

SLE patients with a history of nephritis had higher concentrations of anti-telomere antibodies than patients without nephritis $(p=0.005)$ (table 4$)$. The associations of other tests, except ANA, were also statistically significant ( $\mathrm{p}=0.006$ to 0.049 ).

\section{DISCUSSION}

We found that the ELISA assay for anti-telomeric DNA antibodies was a sensitive and highly specific test for SLE. The most sensitive test (best screening test) was ANA by immunofluorescence, followed by anti-dsDNA (Shield) and anti-telomere. Anti-telomere was clearly more specific than the first two tests. In our study, anti-dsDNA (Inova) and Crithidia immunofluorescence were too insensitive to be clinically useful in the differential diagnosis of SLE, although they were very specific.

An ideal diagnostic test would be sensitive, specific, and have a high PPV and NPV. Increases in sensitivity lead to decreases in specificity and vice versa, and the percentages depend on the cut off level set for positivity among the controls. We present the results for anti-telomere and antidsDNA by the two ELISA assays, choosing values higher than the 98th centile for healthy controls as positive. When the 95th and 99th centile and mean+2 SD were chosen as the cut off point, the conclusions were similar. Table 5 shows that the balance between sensitivity and specificity by antitelomere was comparable with other ELISA assays. Using mean+2 SD or 95th centile as the cut off point would have increased the sensitivity of anti-telomere to $67-68 \%$ without a major loss of specificity.

By combining two assays, the highest sensitivities were reached by ANA together with either anti-telomere $(88 \%)$ or anti-dsDNA (Shield) (86\%). The specificities of these two combinations were, however, quite low and their overall 
Table 5 Anti-telomere and anti-dsDNA by enzyme linked immunosorbent assay in systemic lupus erythematosus and other autoimmune rheumatic diseases

\begin{tabular}{|c|c|c|c|c|c|c|c|}
\hline & Cut off point & Positive & SLE & Sensitivity & Specificity & PPV & NPV \\
\hline Anti-telomere & $\begin{array}{l}\text { 95th centile } \\
\text { 98th centile } \\
\text { 99th centile } \\
\text { Mean+2SD }\end{array}$ & $\begin{array}{l}204 / 379(54 \%) \\
173 / 379(46 \%) \\
93 / 379(25 \%) \\
199 / 379(53 \%)\end{array}$ & $\begin{array}{l}188 / 275 \\
164 / 275 \\
90 / 275 \\
184 / 275\end{array}$ & $\begin{array}{l}68 \% \\
60 \% \\
33 \% \\
67 \%\end{array}$ & $\begin{array}{l}85 \% \\
91 \% \\
97 \% \\
86 \% \\
\end{array}$ & $\begin{array}{l}92 \% \\
95 \% \\
97 \% \\
92 \%\end{array}$ & $\begin{array}{l}50 \% \\
46 \% \\
35 \% \\
49 \%\end{array}$ \\
\hline $\begin{array}{l}\text { Anti-dsDNA } \\
\text { (Shield) }\end{array}$ & $\begin{array}{l}\text { 95th centile } \\
\text { 98th centile } \\
\text { 99th centile } \\
\text { Mean+2SD }\end{array}$ & $\begin{array}{l}265 / 330(80 \%) \\
185 / 330(56 \%) \\
175 / 330(53 \%) \\
244 / 330(74 \%)\end{array}$ & $\begin{array}{l}184 / 205 \\
142 / 205 \\
136 / 205 \\
173 / 205\end{array}$ & $\begin{array}{l}90 \% \\
69 \% \\
66 \% \\
84 \%\end{array}$ & $\begin{array}{l}35 \% \\
66 \% \\
69 \% \\
43 \%\end{array}$ & $\begin{array}{l}69 \% \\
77 \% \\
78 \% \\
71 \%\end{array}$ & $\begin{array}{l}68 \% \\
57 \% \\
55 \% \\
63 \%\end{array}$ \\
\hline $\begin{array}{l}\text { Anti-dsDNA } \\
\text { (Inova) }\end{array}$ & $\begin{array}{l}\text { 95th centile } \\
\text { 98th centile } \\
\text { 99th centile } \\
\text { Mean+2SD }\end{array}$ & $\begin{array}{l}141 / 404(35 \%) \\
87 / 404(22 \%) \\
79 / 404(20 \%) \\
151 / 404(37 \%)\end{array}$ & $\begin{array}{l}121 / 279 \\
82 / 279 \\
75 / 279 \\
129 / 279\end{array}$ & $\begin{array}{l}43 \% \\
29 \% \\
27 \% \\
46 \%\end{array}$ & $\begin{array}{l}84 \% \\
96 \% \\
97 \% \\
82 \%\end{array}$ & $\begin{array}{l}86 \% \\
94 \% \\
95 \% \\
85 \%\end{array}$ & $\begin{array}{l}40 \% \\
38 \% \\
37 \% \\
41 \%\end{array}$ \\
\hline
\end{tabular}

The effect of different cut off points for positivity in healthy controls is shown.

Anti-dsDNA, anti-double-stranded DNA; NPV, negative predictive value; PPV, positive predictive value; SLE, systemic lupus erythematosus.

performance was not better than with individual tests. The combination of anti-telomere with anti-dsDNA (Shield) was as sensitive as but more specific than ANA. This combination was also more sensitive than the corresponding individual assays and had an acceptable specificity. It can thus be recommended as the combination of choice in differentiating SLE from other autoimmune rheumatic diseases.

The prevalence of anti-telomere in SLE and other autoimmune rheumatic diseases in our study was similar to other published values. ${ }^{6-8}$ In a recent study including substantial numbers of patients, Wallace et $a l^{8}$ reported that anti-telomere antibody was present in $49 \%$ of 220 patients with SLE, in $11 \%$ of 18 patients with primary Sjögren's syndrome, and in $8 \%$ of 79 patients with rheumatoid arthritis.

Wallace et al also reported that, in a cohort of 48 SLE patients, anti-telomere was more sensitive than anti-dsDNA by the Farr assay $(71 \% v 50 \%)$. We used the Farr assay in 291 SLE patients and, similarly, found that it was less sensitive than anti-telomere $(43 \% v 60 \%)$. Data on the specificity of the Farr assay were not available, because the test was not carried out in controls with other rheumatic diseases. In general, the Farr assay is considered to be a specific and reasonably sensitive test for diagnosing SLE. ${ }^{16}$

We found a strong correlation of anti-telomere with nephritis, suggesting that the test could be used as an aid for assessing the activity of SLE. In contrast to these findings, Wallace $e t a l^{8}$ reported that anti-telomere antibody positivity did not correlate with any specific symptom, sign, laboratory finding, or disease activity score as assessed by SLEDAI (SLE disease activity index). In their study, however, 35\% of SLE patients with nephritis were anti-telomere positive compared with $21 \%$ of patients without nephritis. Statistical significance was not found, but this may have reflected the relatively small number of patients (48) in the comparison. Obviously, further (longitudinal) studies with larger numbers of patients are needed to evaluate whether anti-telomere relates to the activity of SLE.

Our study design does not fully mirror daily clinical practice in diagnosing SLE. We took serum samples from SLE patients being followed up routinely and from patients with other clearly defined autoimmune rheumatic diseases. A more ideal setting would be to use sera from symptomatic patients referred to the laboratory for determination of antidsDNA for diagnostic purposes. ${ }^{16}$ To use sera from patients with established diagnoses does not, however, influence the relative performance of the different tests. It is also probable that if more samples from patients with active disease had been available, the sensitivities of the tests for SLE would have been greater.

About $0.15 \%$ of the whole genome is composed of the repetitive telomere DNA sequence. Thus it is possible that this sequence plays a role as an immunogen for anti-dsDNA antibody production in SLE. However, at present there is no evidence for sequence specificity of the anti-DNA antibodies in this disease. Likewise there is no evidence for any biological role for such antibodies. Quantitative immunochemical studies are needed in which telomeric DNA is compared with ordinary dsDNA and with single stranded DNA in absorption and cross competition experiments with SLE sera. The results of such studies will eventually tell us if there is something unique in telomeric DNA. ${ }^{17}$

Why should the anti-telomere assay be better than other anti-native DNA antibody assays? Currently, most laboratories use indirect immunofluorescence, the Farr assay, or various ELISA techniques with different types of DNA as antigens. Most ELISA assays use DNA extracted from mammalian thymic tissues. In the Crithidia luciliae immunofluorescence assay, the antigen is eukaryotic kinetoplast DNA, and many Farr and ELISA assays use bacterial or plasmid DNA.

There is evidence for antigenic heterogeneity among the various DNAs. Unmethylated $\mathrm{CpG}$ motifs are frequent in bacterial DNA, and antibodies against bacterial DNA not binding to human DNA can be detected in normal human sera. ${ }^{18}$ The dsDNA antibodies of SLE recognise antigenic epitopes involving the sugar-phosphate backbone of DNA, and react with bacterial, viral, plant, and animal DNA. ${ }^{19}$ Thus the source of DNA may have only a minor effect on the binding of the SLE anti-DNA antibodies. The use of bacterial DNA as antigen-or DNA containing stretches of single stranded DNA-may increase the binding of antibodies of non-SLE patients or normal control subjects and decrease the specificity of the assay. The anti-telomere assay using synthetic mammalian dsDNA of known sequence as antigen is easy to standardise, eliminates binding of non-specific antibodies, and increases the specificity of the assay.

\section{ACKNOWLEDGEMENTS}

E-MS was supported by the Technology Development Centre, Finland; HJ was supported by the HUCH Research Foundation; AM was supported by the Sigrid Juselius Foundation, Finska Läkärsällskapet and HUCH.

\section{Authors' affiliations}

E M Salonen, Department of Virology, Helsinki University Central Hospital (HUCH) Laboratory Diagnostics, Helsinki, Finland 
A Miettinen, T K Walle, HUCH Laboratory Diagnostics, Helsinki, Finland S Koskenmies, J Kere, Department of Medical Genetics, Helsinki University, Helsinki, Finland

H Julkunen, Department of Internal Medicine, Peijas Hospital, HUCH, Vantaa, Finland

\section{REFERENCES}

1 Wallace DJ, Schwartz E, Lin H-C, Peter JB. The "rule-out" lupus consultation: clinical outcomes and perspectives. J Clin Rheumatol 1995; 1:158-64.

2 Cervera R, Khamashta MA, Font J, Sebastiani GD, Gil A, Lavilla P, et al. Systemic lupus erythematosus: clinical and immunological patterns of disease expression in a cohort of 1000 patients. Medicine 1993:72:113-24.

3 Egner W. The use of laboratory tests in the diagnosis of SLE. J Clin Pathol 2000;53:424-32

4 Werle $E$, Blazek $M$, Fiehn W. The clinical significance of measuring different anti-dsDNA antibodies by using the Farr assay, an enzyme immunoassay and a Crithidia luciliae immunofluorescence test. Lupus 1992;1:369-77.

5 James K, Meek G. Evaluation of commercial enzyme immunoassays compared to immunofluorescence and double diffusion for autoantibodies associated with auto-immune diseases. Am J Clin Pathol 1992:97:559-65.

6 Salonen EM, Ruuskanen L, Friman C. Anti-telomere antibodies in SLE. Arthritis Rheum 1996;39(suppl 9):40.

7 Salonen EM, Wallace DJ, Metzger A, Morris R, Avaniss-Aghajani E. Anti-telomere antibodies are highly specific for SLE. Arthritis Rheum 1998:41(suppl 9):247.

8 Wallace DJ, Salonen EM, Avaniss-Aghajani E, Morris R, Metzger AL, Pashinian N. Anti-telomere antibodies in systemic lupus erythematosus: a new
ELISA test for anti-DNA with potential pathogenetic implications. Lupus 2000;9:328-32.

9 Tan EM, Cohen AS, Fries JF, Masi AT, McShane DJ, Rothfield NF, et al. The 1982 revised criteria for the classification of systemic lupus erythematosus. Arthritis Rheum 1982;25:1271-7.

10 Koskenmies S, Widen E, Kere J, Julkunen H. Familial systemic lupus erythematosus in Finland. J Rheumatol 2001;28:758-60.

11 Arnett FC, Edworthy SM, Bloch DA, McShane DJ, Fries JF, Cooper NS, et al. The American Rheumatism Association 1987 revised criteria for rheumatoid arthritis. Arthritis Rheum 1987;31:315-24.

12 Vitali C, Bombardieri S, Moutsopoulos HM, Balestrieri G, Beneivelli W, Bernstein RM, et al. Preliminary criteria for the classification of Siögren's syndrome. Results of an EEC prospective concerted action. Arthritis Rheum 1993;36:340-7.

13 Alarcon-Segovia D, Cardiel MM. Comparison between 3 diagnostic criteria for mixed connective tissue disease. Study of 593 patients. J Rheumatol 1989; $16: 328-34$

14 Subcommittee for Scleroderma. Criteria of the American Rheumatism Association Diagnostic and Therapeutic Committee: preliminary criteria for the classification of systemic sclerosis (scleroderma). Arthritis Rheum 1980;23:581-90.

15 Bohan A, Peter JB. Polymyositis and dermatomyositis. Part I and part II. N Engl J Med 1975;292:344-7, 403-7.

16 Derksen RHWM, Bast EJEG, Strooisma T, Jacobs JWG. A comparison between the Farr radioimmunoassay and a new automated fluorescence immunoassay for the detection of antibodies against double stranded DNA in serum. Ann Rheum Dis 2002;61:1099-102.

17 Reichlin M. Antitelomere antibodies in systemic lupus erythematosus. Lupus 2000;9:317.

18 Pisetsky DS. Antibody responses to DNA in normal immunity and aberrant immunity. Clin Diagn Lab Immunol 1998;5:1-6.

19 Stollar BD. Molecular analysis of anti-DNA antibodies. FASEB $J$ 1994;8:337-42. 